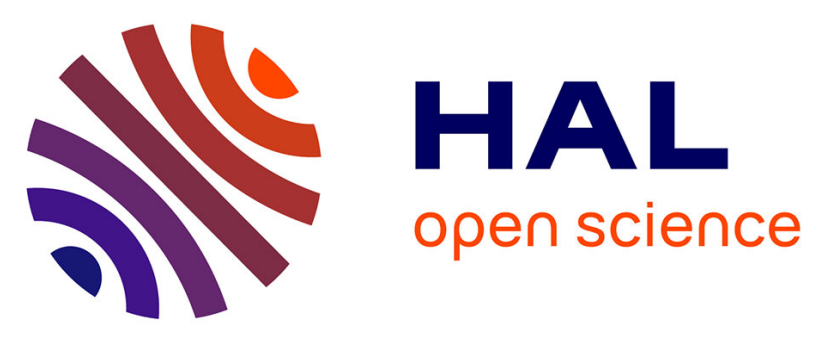

\title{
Interspecific crosses between Pelargonium x hortorum and $P$. quinquelobatum using embryo rescue and molecular characterization of hybrids by an endogenous chs probe
}

\author{
L. Denis-Peixoto, A. Cadic, Jean-Pierre Renou
}

\section{- To cite this version:}

L. Denis-Peixoto, A. Cadic, Jean-Pierre Renou. Interspecific crosses between Pelargonium x hortorum and P. quinquelobatum using embryo rescue and molecular characterization of hybrids by an endogenous chs probe. Plant Breeding, 1997, 116 (2), pp.177-180. 10.1111/j.1439-0523.1997.tb02174.x . hal-01601158

\section{HAL Id: hal-01601158 \\ https://hal.science/hal-01601158}

Submitted on 1 Jun 2020

HAL is a multi-disciplinary open access archive for the deposit and dissemination of scientific research documents, whether they are published or not. The documents may come from teaching and research institutions in France or abroad, or from public or private research centers.
L'archive ouverte pluridisciplinaire HAL, est destinée au dépôt et à la diffusion de documents scientifiques de niveau recherche, publiés ou non, émanant des établissements d'enseignement et de recherche français ou étrangers, des laboratoires publics ou privés.

\section{다(1)(2)}

Distributed under a Creative Commons Attribution - ShareAlikel 4.0 International 


\title{
Interspecific crosses between Pelargonium $\times$ hortorum and $P$. quinquelobatum using embryo rescue and molecular characterization of hybrids by an endogenous chs probe
}

\author{
L. Denis-Peixoto', A. CADic ${ }^{1}$ and J. P. Renou ${ }^{1,2}$ \\ 'INRA CR-Angers, Unité d'Amélioration des Espèces Fruitières et Ornamentales, 42 rue G. Morel, F-49071 Beaucouze \\ Cedex, France; ${ }^{2}$ Corresponding author \\ With 2 figures and 2 tables
}

Received July 2, 1996/Accepted September 17, 1996

Communicated by W. E. Weber

\begin{abstract}
Interspecific hybridizations were performed between Pelargonium $\times$ hortorum (subgenus Ciconium) and a yellow-flowered species. Pelargonium quinquelobatum (subgenus Eumorpha). Hybrids, using embryo rescue, were obtained only when $P$. quinquelobatum was used as the female parent. A polymerase chain reaction (PCR) cloned Pelargonium chs gene fragment was used as probe to characterize hybrids by restriction fragment length polymorphism (RFLP) analysis. Chromatographic flavonoid analysis showed that hybrids could synthesize both flavonol glycosides and anthocyanin in the petals which were pale yellow to pale pink from the proximal to the distal part.
\end{abstract}

Key words: Pelargonium $\times$ hortorum $-P$. quinquelobatum chalcone synthase - embryo rescue - flavonoids - interspecific crosses

The genus Pelargonium contains more than 250 species in 13 sections (van der Walt and Vorster 1988). The 'so-called' geraniums $(P . \times$ hortorum Bailey, Ciconium section), and the ivyleaved geraniums $(P . \times$ hederaefolium Bailey, Dibrachy a section) are the most economically important. Since the beginning of the nineteenth century more than 4000 varieties have been created by hybridization or mutation and it is now difficult to extend the flower colour palette. Thus, there is some interest in using newer techniques to create greater varietal diversity. Attempts have been made to produce somatic hybrids, however, plant regeneration has been reported only for parent protoplasts (Yarrow et al. 1987).

Recently, Agrobacterium-mediated transformation of P. $\times$ hortorum has been reported (Robichon et al. 1995). Modification of Pelargonium pigmentation by this method is, up to now, limited to the antisense-chs strategy (van der Krol et al. 1988). Interspecific hybridization is another field of investigation because of the broad genetic variability in the genus Pelargonium. The main limitation comes from the variation in chromosome numbers ( $x=8,9,10$ or 11 ; Darlington and Wylie 1955), and ploidy level. While intra-subgeneric crosses are generally successful, most inter-subgeneric crosses (i.e. between different sections) fail to produce seeds and hybrids from species with different chromosome numbers are an exception (Horn 1994; Yu and Horn 1984). Thus, embryo rescue has been used to recover hybrids consistently. In this respect, Kakihara et al. (1990) obtained $P . \times$ hortorum $\times$ P. peltatum hybrids; Bentvelsen et al. (1990) succeeded in recovering hybrids between $P$. peltatum and several species of the Ciconium section. The pre- sent report describes for the first time the successful hybridization between a cultivar of $P . \times$ hortorum (Ciconium section) and the pale yellow-flowered wild species $P$. quinquelobatum (Eumorpha section). Restriction fragment length polymorphism (RFLP) analysis with an endogenous chs probe provided evidence of the biparental origin of the hybrids and for that purpose a chalcone-synthase gene fragment was polymerase chain reaction (PCR) cloned. The polymorphism of this multigene family (Niesbach-Klösgen et al. 1987) is observed in these two Pelargonium species. This result clearly indicates that molecular tools can be used at an early stage for the detection of hybrids in Pelargonium breeding. Flavonoid analysis of hybrids and parents gives a preliminary understanding of the yellow-coloured flower inheritance within the genus.

\section{Materials and Methods}

Plant materials: Pelargonium $\times$ hortorum cvs 'Happy Thought'. 'Highfield Promise'. 'Hamelin' and 'Westphalen' (Ciconium section), $P . \times$ hederaefolium cv. 'Ville de Paris' (Dihrachya section) and yellowflowered wild species $P$. quinquelobatum (Eumorpha section) and $P$. aridum (Ligularia section) were used as parents in controlled crosspollinations. All forms were diploid $(2 n=2 x=18)$. Flower buds $(1 \mathrm{~cm}$ long) were emasculated and bagged, and pollen was applied to the stigmas $48 \mathrm{~h}$ later.

For embryo rescue (method adapted from Scemama and Raquin 1990) whole fruits were harvested 19 days after pollination and surfacesterilized in $70 \%$ ethanol. $15 \mathrm{~s}$, calcium hypochlorite $20 \mathrm{~g} / \mathrm{l} .1 \mathrm{~min}$. then washed twice with sterile water. Zygotic immature embryos were explanted aseptically on a sterile 0.5 MS medium (Murashige and Skoog 1962) supplemented with $20 \mathrm{~g} / \mathrm{l}$ saccharose and $6 \mathrm{~g} / \mathrm{l}$ agarose. $\mathrm{pH} 5.7$ Cultures were maintained in vitro at $24^{\circ} \mathrm{C}$, with a $16 \mathrm{~h}$ photoperiod The plantlets were then transplanted into perlite-peat moss $(1: 1)$ and acclimatized in the greenhouse.

Molecular analysis of hybrids: Total DNA was isolated from young leaves (1-g aliquots) according to Doyle and Doyle (1990). Genomic Pelargonium DNA was used as template for amplification of the chs fragment. as described by Sambrook et al. (1989). PCR reaction was performed using Goldstar DNA polymerase (EUROGENTEC. Seraing, Belgium) and two partially degenerated primers flanking a 553-bp region and including an EcoRI and a $\mathrm{XbaI}$ site, respectively (Lurin and Jouanin 1995):

O15 EcoRI: 5'-CG GAA TTC ATG ATG TA(CT) CA(AG) CA(AG) GG(GCT) TGC TT(CT) GC-3';

O16 Xbal: $5^{\prime}$-GC TCT AGA C(AG)C AIG C(AG)C T(GCT)G ACA T(AG)T TIC C-3'. 
Table 1: Results of crosses between Pelargonium quinquelobatum and $P . \times$ hortorum or $P . \times$ hederaefolium

\begin{tabular}{|c|c|c|c|c|c|c|}
\hline Cross & Pollinations & $\begin{array}{c}\text { Early } \\
\text { developing } \\
\text { fruits }\end{array}$ & $\begin{array}{l}\text { Harvested } \\
\text { fruits }\end{array}$ & Seeds & Plants & $\begin{array}{c}\text { True } \\
\text { hybrids }\end{array}$ \\
\hline \multicolumn{7}{|l|}{$P$. quinquelohatum $\times P . \times$ hortorum } \\
\hline 'Westphalen' & 5 & 2 & 2 & 2 & 0 & 0 \\
\hline "Highfield Promise' & 11 & 6 & 6 & 5 & 2 & 2 \\
\hline 'Hamelin' & 27 & 7 & 7 & 8 & 8 & 0 \\
\hline 'Happy Thought' & 2 & 2 & 2 & 2 & 1 & 1 \\
\hline Total & $4 \overline{5}$ & $1 \overline{7}$ & 17 & 17 & 11 & 3 \\
\hline \multicolumn{7}{|l|}{ P. $\times$ hortorum $\times P$. quinquelobatum } \\
\hline 'Westphalen' & 12 & 3 & 0 & 0 & 0 & 0 \\
\hline 'Highfield Promise' & 11 & 2 & 0 & 0 & 0 & 0 \\
\hline 'Hamelin' & 11 & 0 & 0 & 0 & 0 & 0 \\
\hline 'Happy Thought' & 6 & 2 & 0 & 0 & 0 & 0 \\
\hline $\begin{array}{l}P . \times \text { hederaefolium } \times P . \text { quinquelobatum } \\
\text { "Ville de Paris" }\end{array}$ & 72 & $\overline{0}$ & 0 & 0 & 0 & 0 \\
\hline Total & 112 & 7 & 0 & 0 & 0 & 0 \\
\hline
\end{tabular}

The PCR programme was: denaturation $93 \mathrm{C}(5 \mathrm{~min}), 35$ cycles of $93 \mathrm{C}$ (1 min), $50 \mathrm{C}(1 \mathrm{~min}), 72 \mathrm{C}(2 \mathrm{~min})$, followed by a final elongation step at $72 \mathrm{C}(20 \mathrm{~min})$. The PCR product was digested by $E c o$ RI and $\mathrm{Xbal}$ and subcloned into pUC19 according to standard protocols (Sambrook et al. 1989) and partially sequenced by Euro Séquences Gènes Services (ESGS) (Montigny le Bretonneux. France).

Genomic DNA (10- $\mu$ g samples) was digested overnight by EcoRI and HindIII, run on a $0.8 \%$ agarose gel at $5 \mathrm{~V} / \mathrm{cm}$. denatured and transferred to a Hybond $\mathrm{N}$ (Amersham. Slough, UK) nylon membrane according to standard protocols (Sambrook et al. 1989). The chs fragment was labelled with ${ }^{32} \mathrm{P}$ by the random prime method. Hybridization was performed overnight at $62 \mathrm{C}$. The membrane was then washed twice in $2 \times \mathrm{SSPE} / 0.1 \%$ sodium dodecyl sulphate (SDS) at room temperature for $10 \mathrm{~min}$, in $1 \times \operatorname{SSPE} 0.1 \%$ SDS at $62 \mathrm{C}$ for $15 \mathrm{~min}$ and in $0.1 \times \mathrm{SSPE} / 0.1 \% \mathrm{SDS}$ at $62 \mathrm{C}$ for $10 \mathrm{~min}$. Finally, the blot was exposed to Kodak X-OMAT film with two intensifying screens at $-80 \mathrm{C}$ for $48 \mathrm{~h}$.

Flavonoid pigment extraction and chromatography: Fresh petal tissue was extracted in $\mathrm{MeOH}-\mathrm{HCl} 0.1 \%(2 \mathrm{~g} / \mathrm{ml})$ at room temperature according to standard procedures (Harborne 1967). Extracts were filtered through glass wool and concentrated under vacuum. One-microlitre aliquots were loaded for the mono-dimensional highperformance thin layer chromatography (TLC) (cellulose plates. Merck. Nogent Sur Marne. France) of pigments in BAW (n-butanol:acetic acid:water, 4:1:5). The remaining volume was diluted in $2 \mathrm{~N} \mathrm{HCl}(2 \mathrm{ml})$ and digested for $30 \mathrm{~min}$ at $100 \mathrm{C}$. Aglycones were extracted with $300-$ $500 \mu \mathrm{l}$ of isoamyl alcohol. 5-10 $\mu \mathrm{l}$ were then used for the two-dimensional TLC of aglycones (cellulose plates, Merck) using formic acid:HCl:water (100:2.5:37.5) and n-amyl alcohol:acetic acid:water (2:1:1). The chromatograms were analysed under visible light (anthocyanins) and ultraviolet light (flavonols).

\section{Results \\ Hybrids}

From 157 pollinations between $P$. quinquelobatum and cultivated species, fruits could be harvested only when $P$. quinquelobatum was used as the female parent (Table 1). When $P$. quinquelobatum was the male parent some fruits began to grow after pollination, but they died after 8-10 days.

Eleven plants were greenhouse-acclimatized after embryo rescue from crosses between $P$. quinquelobatum (female) and $P . \times$ hortorum (male). However, eight showed a female phenotype, suggesting that they were self-pollination products. $P$. quinquelobatum is highly self-fertile and there is a high risk of self-fertilization even if emasculation is performed early.
Nevertheless, three plants looked like hybrids with some intermediate characters - lobate leaves with zonation and less elongated than the female parent (Fig. 1a). The two hybrids from 'Highfield Promise' did not grow quickly and failed to flower. Conversely, the hybrid P. quinquelobatum $\times$ 'Happy Thought' grew normally and bloomed quickly (Fig. 1b). Floret peduncles showed an intermediate $10 \mathrm{~cm}$ average length which would be at least $20 \mathrm{~cm}$ for those of $P$. quinquelobatum. There were eight to nine flowers per floret, the petals were pale yellow at the proximal part and pale pink at the distal part (Fig. lc).

Twelve crosses between $P$. aridum $\times P$. $\times$ hortorum were performed. and fruits were obtained only when $P$. aridum was used as the female parent. Three plants were greenhouse acclimatized. However, all three plants showed a female phenotype suggesting they were products of self-pollinations (confirmed by RFLP analysis).

\section{PCR cloning of the chs probe}

A 553-bp PCR chs fragment was amplified from $P . \times$ hederaefolium genomic DNA and checked first by hybridization with a Petunia chs $A$ probe. The fragment was subsequently cloned in the Xbal and EcoRI sites of pUC 19 and partially sequenced (single strand monodirectional sequencing). A deduced amino acid sequence of 156 residues corresponding to the 468 nucleotides analysed was then compared with the chs consensus sequence of Niesbach-Klösgen et al. (1987), revealing a high degree of homology $(80.9 \%)$. The sequence will appear in the EMBL nucleotide sequence database under the accession number X 95801 .

\section{RFLP analysis}

The characterization of hybrids was achieved by Southern blot analysis using the 553-bp chs fragment as probe. Figure 2 shows the chs hybridization pattern of the hybrid $P$. quinquelobatum $\times P . \times$ hortorum compared with its parents. For both restriction patterns, the parents showed two major bands (that probably correspond to largely homologous sequences) and several faint bands (that probably correspond to related sequences in the chs multigene family). The hybrid showed in both cases bands of biparental origin. The EcoRI restriction pattern indicates two major bands at 5 and $10 \mathrm{kbp}$ for $P$. quinquelobatum and two closed bands at $\approx 7 \mathrm{kbp}$ for $P . \times$ hortorum. 

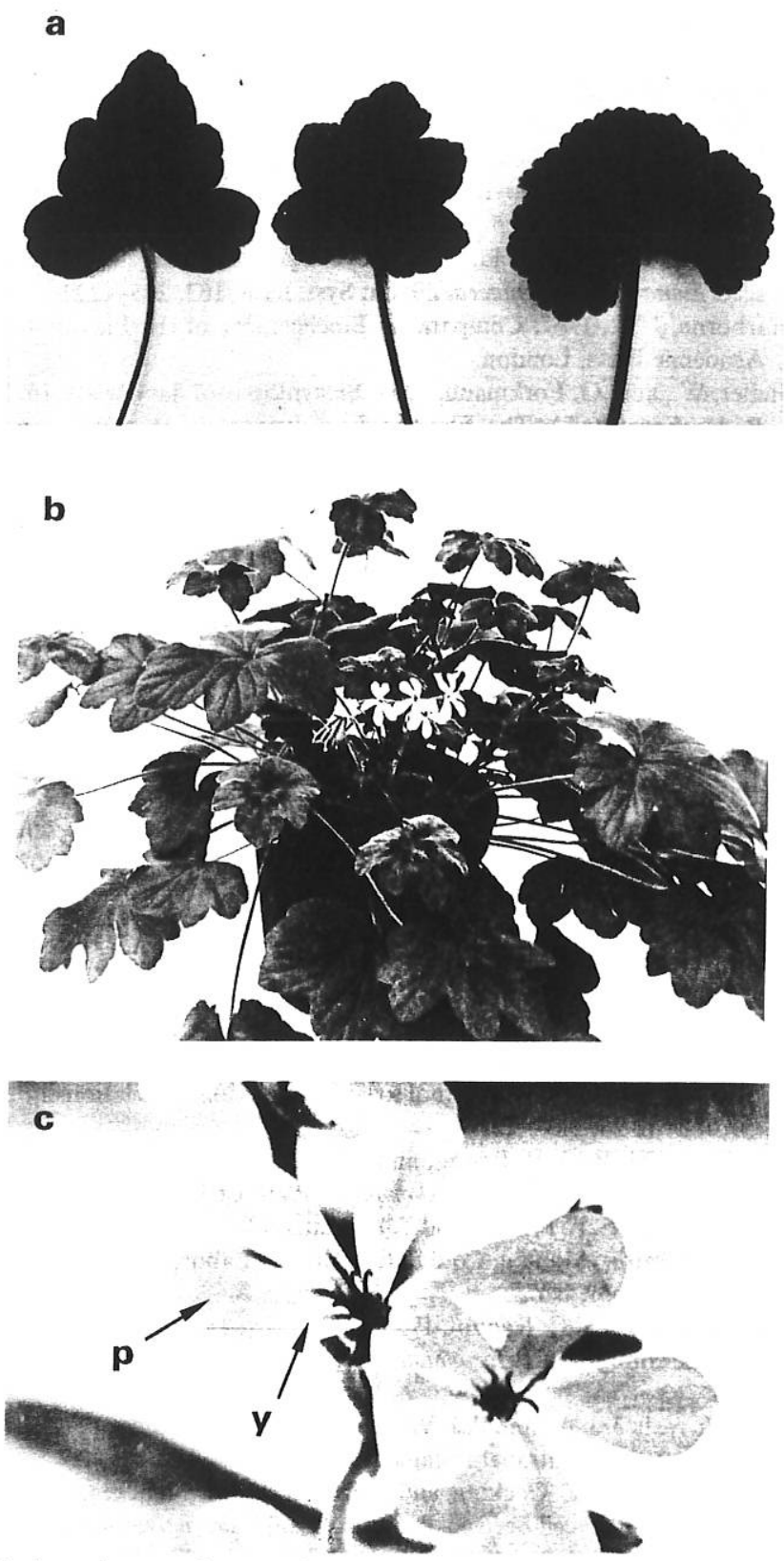

Fig. 1: a. Leaves from Pelargonium quinquelobatum (left), hybrids (middle) and $P . \times$ hortorum (right): b. hybrid $P$. quinquelobatum $\times$ $P . \times$ hortorum ('Happy Thought'): c: hybrid flowers pale yellow (Y) to pale pink $(\mathrm{P})$

The four bands are present in the hybrid. The HindIII pattern revealed two major bands at 1.9 and $3.2 \mathrm{kbp}$ for $P$. quinquelobatum and two bands at 1.8 and $\approx 12 \mathrm{kbp}$ for $P$. $\times$ hortorum, whereas the hybrid contains the two maternal bands and only the largest paternal band. Currently, no data are available for the heterozygosity level of the parental genotypes. However, the HindIII restriction pattern shows that $P$. quinquelobatum bands were both transmitted to the hybrid, in this case the maternal plant would be homozygous for both (one locus containing a HindIII site or two loci). Only one band of $P . \times$ hortorum was transmitted to the hybrid. thus the male parent might be heterozygous at this locus. In both restriction patterns the hybrids present bands from the two parents. This result clearly indicates that the plant analysed is really a hybrid between $P$. quinquelobatum and $P . \times$ hortorum. The other two hybrids gave the same hybridization pattern with bands of both parents

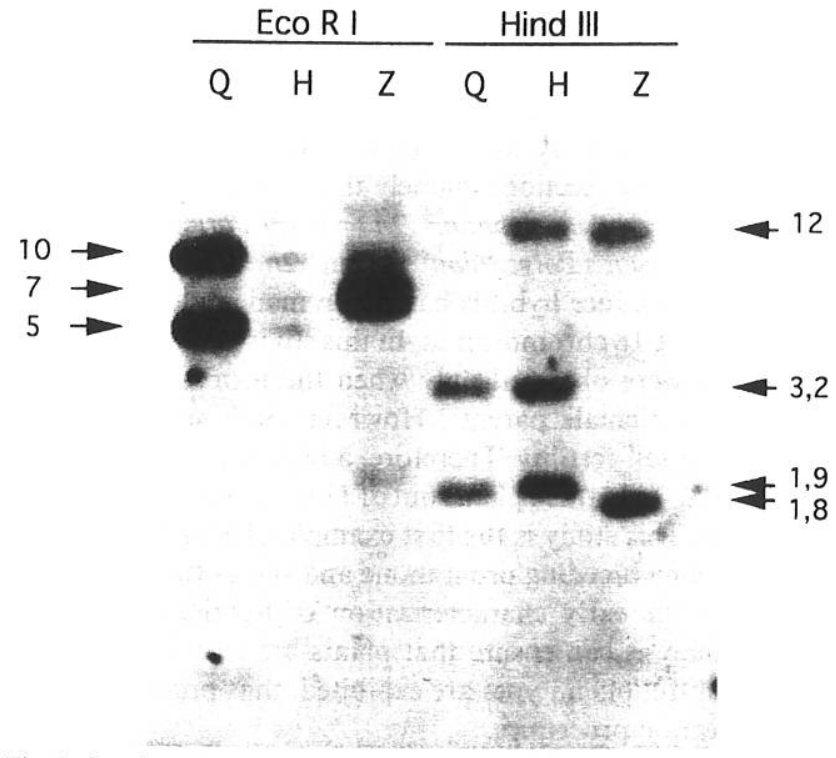

Fig. 2: Southern-blot analysis of Pelargonium quinquelobatum (Q) $P . \times$ hortorum cv. 'Happy Thought' $(\mathrm{Z})$ and hybrid $(\mathrm{H})$ digested by EcoRI and HindIII. Probe: chs. Fragment size is expressed in kbp

(data not shown). Conversely, RFLP analysis of the presumed hybrids ' $P$. quinquelobatum $\times P$. $\times$ hortorum' exhibiting a female phenotype and of the presumed ' $P$. aridum $\times P$. $\times$ hortorum' hybrids showed exactly the same hybridization pattern for hybrids and their female parent, supported the hypothesis that they were products of self-pollination (data not shown).

\section{Flavonoid analysis}

Flavonoid chromatograms showed both the presence of flavonol glycosides and low amounts of anthocyanins in the $P$. quinquelobatum $\times$ 'Happy Thought' hybrid whereas large amounts of flavonol glycosides are present only in P. quinquelobatum flowers and anthocyanins are only present in P. $\times$ hortorum flowers. Aglycone analysis by two-dimensional TLC confirmed that the hybrid contains low amounts of paeonidin and myricetin and large amounts of kaempferol and quercetin (Table 2).

\section{Discussion}

The objective of this study was to evaluate the possibility of extending the flower colour palette in the cultivated species of Pelargonium by interspecific hybridization. This is the first report of the production of hybrids between $P$. quinquelobatum and $\mathrm{P} \times$ hortorum. Only one case of hybridization between sections Eumorpha and Dibrachya has previously been reported (Gibby and Westfold 1986). However, the authors described a wild plant containing 26 chromosomes and of a presumed origin $P$. alchemilloides $\times P$. peltatum $\mathrm{L}$.

Table 2: Flavonoid analysis of parents and hybrid. $M=$ myricetin. $\mathrm{Q}=$ quercetin. $\mathrm{K}=$ kaemferol, $\mathrm{P}=$ paeonidin, $\mathrm{Pe}=$ pelargonidin . ++ main component, + comp. present, $\bigcirc$ traces, - absent

\begin{tabular}{lcccccc}
\hline & $\mathrm{M}$ & $\mathrm{Q}$ & $\mathrm{K}$ & $\mathrm{P}$ & $\mathrm{Pe}$ \\
\hline Pelargonium quinquelobatum & + & ++ & ++ & - & - \\
P. quinquelobatum $\times$ P. $\times$ hortorum & + & ++ & ++ & + & - \\
P. $\times$ hortorum cv. 'Happy Thought' & - & - & 0 & ++ & ++ \\
\hline
\end{tabular}


Embryo rescue by in vitro culture has become a useful tool in interspecific hybridization, already reported by Bentvelsen et al. (1990) between the two related sections Ciconium and Dibrachya. This study shows that such a technique can be extended to other sections, namely the three pale yellow-flowered species $P$. quinquelobatum $(2 n=18), P$. aridum $(2 n=18)$ and $P$. gibbosum (Polyactium section, $2 n=22$ ). Until now, attempts to produce hybrids have been made only by crossing species having 18 chromosomes. In this study, developing fruits and plants were obtained only when the forms with $2 n=18$ were used as female parents. However, both species show a high level of self-fertility. Therefore, a high self-pollination risk exists, and so only three plants out of 11 have been characterized as hybrids. This study is the first example of RFLP analysis in a Pelargonium breeding programme and shows that it could be of use for the early characterization of hybrids. Restriction pattern analysis can ensure that plants are true hybrids, even when doubtful phenotypes are exhibited, thus providing a tool in the selection procedure.

Flavonoid analysis had shown that the pale yellow colour of $P$. quinquelobatum petals results from the large amounts of flavonol glycosides, whereas the $P . \times$ hortorum parent contains only anthocyanins. Previous analyses have shown that flavonol glycosides are not detectable in mature flowers of $P . \times$ hortorum and $P . \times$ hederaefolium cultivars - even in white ones (data not shown). This suggests that neither species, in the petal tissue, can oxidize dihydrofla vonols which are transformed into anthocyanidins by the dihydroflavonol reductase (DFR) and anthocyanidin synthase (ANS) (for review, see Heller and Forkmann 1993). Lack of significant flavonol synthase (FLS) activity might occur at the regulatory level. However, the hybrid synthesizes both anthocyanins and flavonols in mature petals, indicating both FLS and DFR activity on dihydroflavonols. This result suggests that production of a yellow-coloured flower would involve crosses with a white $P . \times$ hortorum genotype lacking DFR activity.

\section{Acknowledgements}

The authors thank G. Michel and S. Hanteville for technical assistance, C. Rosati for critical reading of the manuscript. and D. Lejeune (Bourges germplasm collection. France) for providing the wild Pelargonium species. This work was supported by 'Union France Pelargonium'.

\section{References}

Bentvelsen. G. C. M., H. G. W. Stemkens, and P. Tjeertes, 1990:
Interspecific crosses in Pelargonium and the application of embryo rescue methods. Proc. Symp. Eucarpia, Section Ornamentals, Wageningen, 104-109.

Darlington, C. D., and A. P., Wylie, 1955: Chromosome Atlas of Flowering Plants. Allen and Unwin Ltd., London.

Doyle, J. J., and J. L. Doyle. 1990: Isolation of plant DNA from fresh tissue. Focus 12, 13-15.

Gibby, M., and J. Westfold. 1986: A cytological study of Pelargonium sect. Eumorpha (Geraniaceae). Plant Syst. Evol. 153, 205-222.

Harborne, J. B., 1967: Comparative Biochemistry of the Flavonoids. Academic Press, London.

Heller, W., and, G. Forkmann, 1993: Biosynthesis of flavonoids. In: J. B. Harborne (ed.). The Flavonoids: Advances in Research Since 1986, 499-534. Chapman and Hall Ltd., London, UK.

Horn, W., 1994: Interspecific crossability and inheritance in Pelargonium. Plant Breeding 113, 3-17.

Kahikara, F., M. Kato, and S. Tokumasu, 1990: In vitro cultures in hybridization between zonal geranium (Pelargonium $\times$ hortorum Bailey) and ivy-leaved geranium ( $P$. peltatum Ait.) and the characteristics of hybrid plants. Int. Hort. Congr. Firenze, Abstracts, 3143.

van der Krol, A. R., P. E. Lenting, J. Veenstra, I. M. Meer, R. E. van der Koes, A. G. M. Gerats, J. N. M. Mol, and A. R. Stuitje, 1988: An anti-sense chalcone synthase gene in transgenic plants inhibit flower pigmentation. Nature 333, 866.

Lurin, C., and L. Jouanin. 1995: RFLP of RT-PCR products: application to the expression of chs multigene family in poplar. Mol Breeding 1, 411-417.

Murashige, T., and F. Skoog. 1962: A revised medium for rapid growth and bioassays with tobacco tissue culture. Physiol. Plantarum 15, 473-497.

Niesbach-Klösgen, U., E. Barzen, J. Bernhardt, W. Rhode, S. SchwarzSommer, H. J. Reif. U. Wienand, and H. Saedler, 1987: Chalcone synthase genes in plants: a tool to study evolutionary relationship. J. Mol. Evol. 26, 213-225.

Robichon, M. P., J. P. Renou, and R. Jalouzot, 1995: Genetic transformation of Pelargonium $\times$ hortorum. Plant Cell Rep. 15, 63-67.

Sambrook, J., E. F. Fritsch. and T. Maniatis, 1989: Molecular Cloning: A Laboratory Manual, Cold Spring Harbor Laboratory Press, Cold Spring Harbor, NY.

Scemama, C., and C. Raquin. 1990: An improved method for rescuing zygotic embryos of Pelargonium $\times$ hortorum Bailey. J. Plant Physiol. 135, 763-765.

van der Walt, J. J. A., and P. J. Vorster, 1988: Pelargoniums of Southern Africa, Vol. 3. National Botanic Gardens, Kirstenbosch.

Yarrow. S. A., E. C. Cocking. and J. P. Power, 1987: Plant regeneration from cultured cell-derived protoplasts of Pelargonium aridum, $P$. $\times$ hortorum and $P$. peltatum. Plant Cell Rep. 6, 102-104.

Yu, S. N., and W. Horn. 1984: Crosses between Pelargonium spp. of different taxonomic sections. Proc. Symp. EUCARPIA, Section Ornamentals, Svedborg. 49-59. 